УДК 66-97

O.А. Жученко, канд. техн. наук, доц. ORCID 0000-0001-5611-6529,

А.П. Коротинський, асп. ORCID 0000-0002-6309-5970

Національний технічний університет України «Київський політехнічний інститут імені Ігоря Сікорського»

\title{
ДОСЛІДЖЕННЯ ВПЛИВУ НАДЛИШКУ ПОВІТРЯ НА ПРОЦЕС НАГРІВАННЯ БАГАТОКАМЕРНОЇ ПЕЧІ ВИПАЛЮВАННЯ ДИМОВИМИ ГАЗАМИ
}

\begin{abstract}
Якісне управління процесом випалювання вуглецевих виробів иляхом зміни параметрів технологічного режиму дозволяе досягнути меншого виходу бракованої продукиї. Саме тому моделювання основних етапів процесу випалювання з врахуванням максимальної кількості факторів впливу, яке дозволить мінімізувати час та вартість виробництва готової продукиії є важливою науковою задачею. У зв'язку з тим, щзо виконати дослідження на промисловому обладнанні неможливо з технічних та економічних причин, як метод дослідження використовувалося математичне моделювання.

Проведено дослідження впливу надлишку витрати повітря, щзо спалюється разом з природним газом, на температурні поля камери печі на етапі ї̈ нагрівання димовими газами. Виявлено закономірності зміни середнього значення перепаду температур по заготовкам на різних етапах нагрівання при різних режимах роботи. Досліджено особливості характерних зон печі під час процесу нагрівання камери печі димовими газами.

Побудовані температурні поля камери печі та заготовок, на підставі яких проаналізовані перепади температур по заготовках, що суттєво впливають на якість вихідної продукції. Представлені гістограми мінімальних та максимальних температур по заготовках наприкінці процесу нагрівання для різних режимів витрат повітря.
\end{abstract}

Ключові слова: випалювання вуглецевих виробів, димові гази, багатокамерна піч, температурні поля, перепад температур, надлишок повітря.

Вступ

Широкого застосування у різних галузях промисловості знайшли вуглецеві вироби у вигляді графітованих електродів, ніпелів, вуглецевих блоків, анодів тощо.

Одним із ключових етапів виробництва вуглеграфітових виробів, де вироби набувають механічної міцності, термостійкості, електро- та теплопровідності $\epsilon$ випалювання - термічна обробка при температурах $900-1300{ }^{\circ} \mathrm{C}$.

У зв’язку з цим підвищення ефективності процесу випалювання вуглецевих виробів є актуальною науково-технічною задачею.

\section{Мета та завдання}

Процес випалювання умовно розділяють на три етапи: нагрівання димовими газами, «камера під вогнем» та охолодження.

Якість вуглецевих виробів визначається державним стандартом ДСТУ 4494:2005, технічними умовами ТУ У 27.9-00196204-005:2013, в яких висуваються вимоги до механічної міцності, термостійкості, електро- та теплопровідності, густини, пористості, модуля пружності, вмісту золи тощо. Всі ці показники у процесі випалювання заготовок повністю визначаються температурним режимом процесу [1-2].

Оскільки нагрівання камери печі димовими газами є першим етапом процесу випалювання, то збільшення однорідності температурного поля заготовок на цьому етапі сприяє зменшенню його нерівномірності на наступних стадіях обробки.

Саме тому задача визначення залежності температурних полів при нагріванні камери печі димовими газами від технологічних параметрів процесу $\epsilon$ актуальною. До таких параметрів відносяться: розрідження, витрата палива, надлишок повітря.

Метою даного дослідження є визначення впливу надлишку витрати повітря, що спалюється разом 3 природним газом, на температурні поля процесу випалювання вуглецевих виробів на етапі їх нагрівання димовими газами.

Опис умов досліду

У дослідженні розглядається касета печі випалювання з розміром $3,8 \times 0,76 \times 4,05$ м, у якій розміщено 5 заготовок діаметрами 700 мм та висотою 2100 мм. Прийнято, що тривалість процесу випалювання 480

(C) О.А. Жученко, А.П. Коротинський, 2018 
ISSN 1813-5420 (Print). Енергетика: економіка, технології, екологія. 2018. № 1

год., число камер на охолодженні - 1, число камер під вогнем - 1, число камер на підігріві димовими газами - 4, відповідно темп випалювання складає 96 год. Розглядається одна камера, що послідовно проходить 4 етапи підігріву димовими газами.

Прийнято, що початкова температура всіх складових касети печі складає $300 \mathrm{~K}$. Температура димових газів та розрідження у камерах печі наведено у табл. 1 [3].

Таблиця 1 - Розподіл температур і розріджень по камерам печі

\begin{tabular}{|l|c|c|c|c|c|}
\hline Камери & вогнева & 1 & 2 & 3 & 4 \\
\hline $\mathrm{t},{ }^{\circ} \mathrm{C}$ & 1300 & 1080 & 830 & 680 & 560 \\
\hline Па 9,80665 & $0,5-1$ & 1,2 & 2,5 & 4 & 5,6 \\
\hline
\end{tabular}

Для подальшого числового моделювання прийнято наведені в таблицях 2-5 фізичні властивості матеріалів печі випалювання та їі завантаження відповідно до [2;4-5]:

Таблиця 2 - Теплофізичні властивості вогнетривкого шамоту

\begin{tabular}{|l|l|l|l|}
\hline $\mathrm{T}, \mathrm{K}$ & $\rho, \mathrm{\kappa} / \mathrm{M}^{3}$ & $\mathrm{Cp}$, Дж/(кг $\mathrm{K})$ & $\lambda, \mathrm{BT} /(\mathrm{M} \cdot \mathrm{K})$ \\
\hline 273 & 1900 & 675 & - \\
\hline 323 & 1900 & 797 & - \\
\hline 373 & 1900 & 877 & - \\
\hline 423 & 1900 & 933 & - \\
\hline 473 & 1900 & 975 & 0,99 \\
\hline 523 & 1900 & 1008 & 1,14 \\
\hline 773 & 1900 & 1111 & 1,29 \\
\hline 1023 & 1900 & 1176 & 1,44 \\
\hline 1273 & 1900 & 1230 & 1,59 \\
\hline 1523 & 1900 & 1279 & \\
\hline
\end{tabular}

Таблиця 3 - Теплофізичні властивості матеріалу заготовок

\begin{tabular}{|c|c|c|c|}
\hline $\mathrm{T}, \mathrm{K}$ & $\rho, \kappa \Gamma / \mathrm{M}^{3}$ & $\mathrm{Cp}$, Дж/(кг·К) & $\lambda, \mathrm{BT} /(\mathrm{M} \cdot \mathrm{K})$ \\
\hline 273 & 1635 & 690 & 8 \\
\hline 400 & 1635 & 893 & - \\
\hline 500 & 1635 & 1160 & 8,3 \\
\hline 600 & 1635 & 1315 & - \\
\hline 700 & 1635 & 1423 & - \\
\hline 800 & 1635 & 1501 & 8,5 \\
\hline 900 & 1635 & 1566 & - \\
\hline 1000 & 1635 & 1620 & 8,8 \\
\hline 1100 & 1635 & 1669 & - \\
\hline 1200 & 1635 & 1710 & 9,3 \\
\hline 1400 & 1635 & 1790 & - \\
\hline
\end{tabular}


ISSN 1813-5420 (Print). Енергетика: економіка, технологіï, екологія. 2018. № 1

Таблиця 4 - Теплофізичні властивості теплоізоляційної шихти

\begin{tabular}{|l|l|l|c|}
\hline $\mathrm{T}, \mathrm{K}$ & $\rho, \mathrm{\kappa} / \mathrm{M}^{3}$ & $\mathrm{Cp}$, Дж/(кг·K) & $\lambda, \mathrm{BT} /(\mathrm{M} \cdot \mathrm{K})$ \\
\hline 273 & 800 & 690 & 0,35 \\
\hline 400 & 800 & 893 & - \\
\hline 500 & 800 & 1160 & - \\
\hline 600 & 800 & 1315 & - \\
\hline 700 & 800 & 1423 & - \\
\hline 800 & 800 & 1501 & - \\
\hline 900 & 800 & 1566 & - \\
\hline 1000 & 800 & 1620 & 1,25 \\
\hline 1100 & 800 & 1669 & - \\
\hline 1200 & 800 & 1710 & - \\
\hline 1400 & 800 & 1790 & - \\
\hline
\end{tabular}

Таблиця 5 - Теплофізичні властивості повітря

\begin{tabular}{|c|c|c|}
\hline $\mathrm{T}, \mathrm{K}$ & Сp, Дж/(кг·К) & $\lambda, \mathrm{BT} /(\mathrm{M} \cdot \mathrm{K})$ \\
\hline 273 & 1005 & 0,0244 \\
\hline 373 & 1009 & 0,0321 \\
\hline 473 & 1026 & 0,0393 \\
\hline 573 & 1047 & 0,046 \\
\hline 673 & 1068 & 0,0521 \\
\hline 773 & 1093 & 0,0574 \\
\hline 873 & 1114 & 0,0622 \\
\hline 973 & 1135 & 0,0671 \\
\hline 1073 & 1156 & 0,0718 \\
\hline 1173 & 1172 & 0,0763 \\
\hline 1273 & 1185 & 0,0807 \\
\hline 1373 & 1197 & 0,085 \\
\hline 1473 & 1210 & 0,0915 \\
\hline
\end{tabular}

\section{Розрахунок витрати димових газів}

Враховуючи, що нагрівання камери печі відбувається димовими газами у результаті горіння природного газу, для проведення чисельного моделювання необхідно провести розрахунок витрати димових газів у залежності від надлишку повітря, що йде на подальше горіння палива.

Теоретично потрібна витрата повітря для горіння залежить від складу палива, а для природного газу визначається таким чином [6]:

$$
L_{0}=0,0476\left(2 \mathrm{CH}_{4}+3,5 \mathrm{C}_{2} \mathrm{H}_{6}+5 \mathrm{C}_{3} \mathrm{H}_{8}+6,5 \mathrm{C}_{4} \mathrm{H}_{10}+8 \mathrm{C}_{5} \mathrm{H}_{12}\right)
$$


де $\mathrm{CH}_{4}, \mathrm{C}_{2} \mathrm{H}_{6} \ldots$ - відсоткові відношення

Дійсна витрата сухого повітря з урахуванням коефіцієнта витрати повітря [6]:

$$
L_{a}=a L_{0}
$$

де $a$ - коефіцієнт витрати повітря, що показує відношення дійсної кількості повітря, введеного для горіння, до теоретично потрібного. Для газу та мазуту коефіцієнт витрати повітря $a=1,05-1,20$ [6].

При повному згоранні палива утворюються продукти горіння у вигляді $\mathrm{CO}_{2}, \mathrm{H}_{2} \mathrm{O}, \mathrm{SO}_{2}$ та $\mathrm{N}_{2}$. Якщо горіння відбувається з надлишком повітря, то у димових газах буде присутній кисень. Загальна витрата продуктів горіння при надлишку повітря буде

$$
V_{a}=V_{C O_{2}}+V_{S_{2}}+V_{N_{2}}+V_{H_{2} O}+V_{O_{2}}
$$

де $V_{\mathrm{CO}_{2}}, V_{\mathrm{SO}_{2}}, V_{\mathrm{N}_{2}}, V_{\mathrm{H}_{2}} \mathrm{O}, V_{\mathrm{O}_{2}}$ - об'єми продуктів горіння.

Об’єм продуктів горіння для природного газу можна визначити так [6]:

$$
\begin{gathered}
V_{O_{2}}=0,21 L_{0}(a-1) \\
V_{\mathrm{CO}_{2}}=0,01\left(\mathrm{CO}_{2}+\mathrm{CH}_{4}+2 \mathrm{C}_{2} \mathrm{H}_{6}+3 \mathrm{C}_{3} \mathrm{H}_{8}+4 \mathrm{C}_{4} \mathrm{H}_{10}+5 \mathrm{C}_{5} \mathrm{H}_{12}\right) \\
V_{\mathrm{H}_{2} \mathrm{O}}=0,01\left(2 \mathrm{CH}_{4}+3 \mathrm{C}_{2} \mathrm{H}_{6}+4 \mathrm{C}_{3} \mathrm{H}_{8}+5 \mathrm{C}_{4} \mathrm{H}_{10}+6 \mathrm{C}_{5} \mathrm{H}_{12}+\mathrm{H}_{2} \mathrm{O}+0,16 \mathrm{dL}_{a}\right) \\
V_{N_{2}}=0,79 L_{a}+0,01 N_{2}
\end{gathered}
$$

де $\mathrm{CH}_{4}, \mathrm{C}_{2} \mathrm{H}_{6} \ldots$ - відсоткові відношення, $L$ - теоретично потрібна витрата сухого повітря для горіння, $\mathrm{L}_{a}$ - дійсна витрата сухого повітря.

Для складу газу, наведеного у табл.6

Таблиця 6 - Склад природного газу.

\begin{tabular}{|c|c|c|c|c|c|c|c|c|}
\hline $\mathrm{CH}_{4}$ & $\mathrm{C}_{2} \mathrm{H}_{6}$ & $\mathrm{C}_{3} \mathrm{H}_{8}$ & $\mathrm{C}_{4} \mathrm{H}_{10}$ & $\mathrm{C}_{5} \mathrm{H}_{12}$ & $\mathrm{CO}_{2}$ & $\mathrm{~N}_{2}$ & $\mathrm{H}_{2} \mathrm{O}$ & Сума \\
\hline 93,0 & 1,2 & 0,7 & 0,4 & 0,2 & 0,2 & 3 & 1 & 100 \\
\hline
\end{tabular}

та при надлишку повітря $a=1,2$ та $a=1,1$ відповідно отримуємо:

Загальна витрата продуктів горіння:

$$
V_{\partial u м}=B V_{a}
$$

$$
\begin{aligned}
& V_{a=1,2}=(1,003+2,146+8,953+0,396) \cdot 30=375 \text { м3/год } \\
& V_{a=1,1}=(1,003+2,131+8,217+0,198) \cdot 30=346,5 \text { м3/год }
\end{aligned}
$$

Відповідно до витрати палива $30 \mathrm{~m}^{3} /$ год, витрата димових газів при надлишку повітря $a=1,2$ складає $375 \mathrm{~m}^{3} /$ год, при надлишку повітря $a=1,1-346,5 \mathrm{~m}^{3} /$ год.

\section{Результати дослідження}

У результаті проведеного моделювання (див. рис. 1) наприкінці першого етапу нагрівання печі димовими газами при надлишку повітря $a=1,1$ та $a=1,2$ при максимальній температурі димових газів 833 $\mathrm{K}$ та розрідженні 55 Па отримано: максимальними є температури стінок вогневого колодязя, що складають $557 \mathrm{~K}$ при $a=1,2$, а при $a=1,1$ досягає $549 \mathrm{~K}$; мінімальні температури - температури протилежних стінок при $a=1,2$ складає $332 \mathrm{~K}$, при $a=1,1$ становить $330 \mathrm{~K}$. Відповідно перепад температур по всьому об'ємові касети складає $225 \mathrm{~K}$ та $219 \mathrm{~K}$.

При збільшенні витрати димових газів температури по всьому об'ємові касети збільшується, проте збільшується і перепад температур. 
K

a)

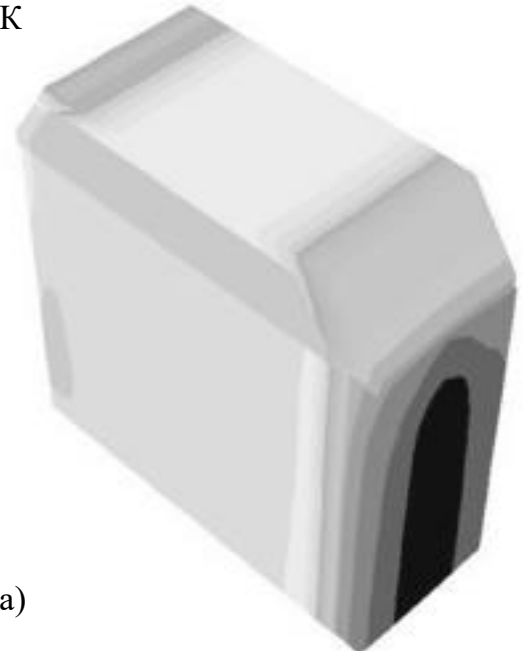

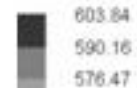

576.47

56279

54910

53542

52173

50e os

40436

48067

46690

45330

43262

42583

412.25

39856

3848

371.19

35751

343.62

390.14
K

б)

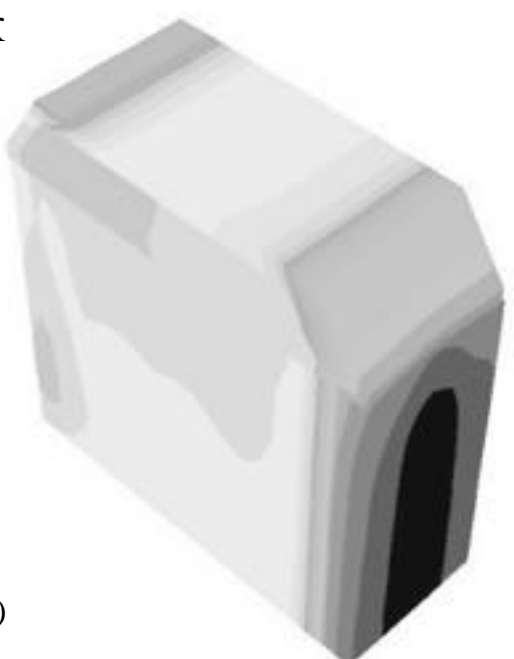

Рисунок 1 - Температурні поля касети при нагріванні димовими газами наприкінці першого етапу:а) при надлишку повітря a=1,2; б) при надлишку повітря $\mathrm{a}=1,1$

3 рис. 1 видно наявність трьох особливих зон печі. Зона 1 - «гаряча зона» печі - зона, де температура досягає максимуму. Наявність цієї зони обумовлена розташуванням тут газового каналу, через який подаються димові гази, а тому і значення температур тут найвищі.

Зона 2 - «підсклепінчата зона» печі. Особливість цієї зони полягає у ії розташуванні. У зв'язку з тим, що під склепінням печі завжди знаходиться велика кількість димових газів, то і нагрівання зони 2 відбувається досить інтенсивно у порівнянні з іншими частинами касети.

Зона 3 - «холодна зона» печі. Наявність даної зони обумовлена значним охолодженням димових газів, температура яких значно нижче у зв'язку з їх охолодженням при проходжені газового тракту печі. Тому і нагрівання у цій зоні відбувається найдовше.

Результати дослідження температурних полів пересипки наприкінці першого етапу нагріву показали, що температурні поля в обох випадках майже однакові та відрізняються лише значеннями температур. Перепади температур по всьому об'ємові пересипки досить значні та становлять близько 170 К. Результати моделювання демонструються на рис. 2.

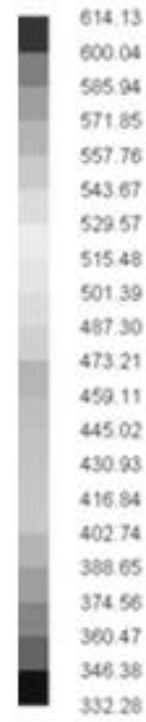

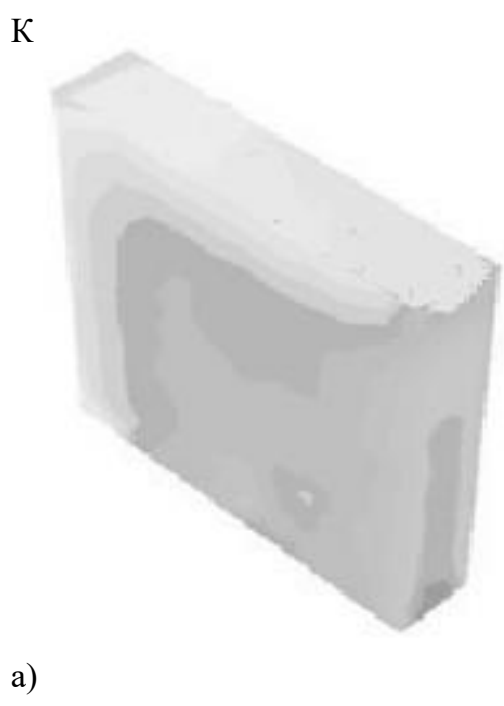

a)

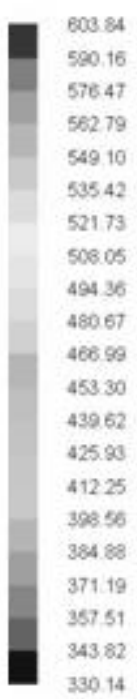

K

б)

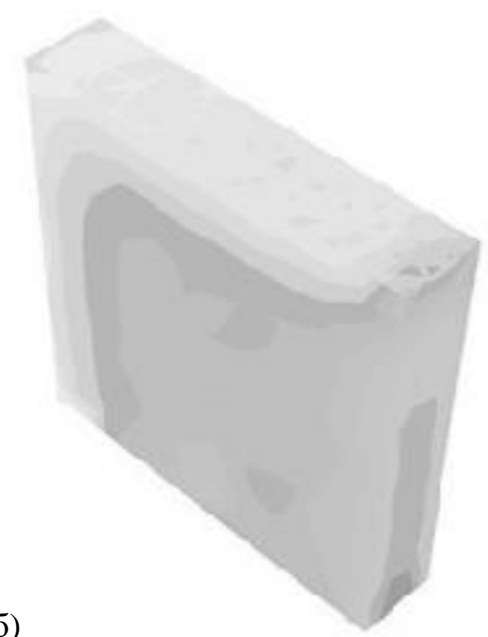

Рисунок 2 - Температурні поля пересипки при нагріванні димовими газами наприкінці першого етапу:а) при надлишку повітря $\mathrm{a}=1,2$; б) при надлишку повітря $\mathrm{a}=1,1$ 


\section{ISSN 1813-5420 (Print). Енергетика: економіка, технології, екологія. 2018. № 1}

Проведені дослідження показали, що температура заготовок зменшується з верху до низу печі, що пояснюється зменшенням температури димових газів при проходженні газового тракту камери печі. Очевидним є перепад температури заготовок - від більш теплої сторони печі до більш холодної. Результати наведені на рис. 3.
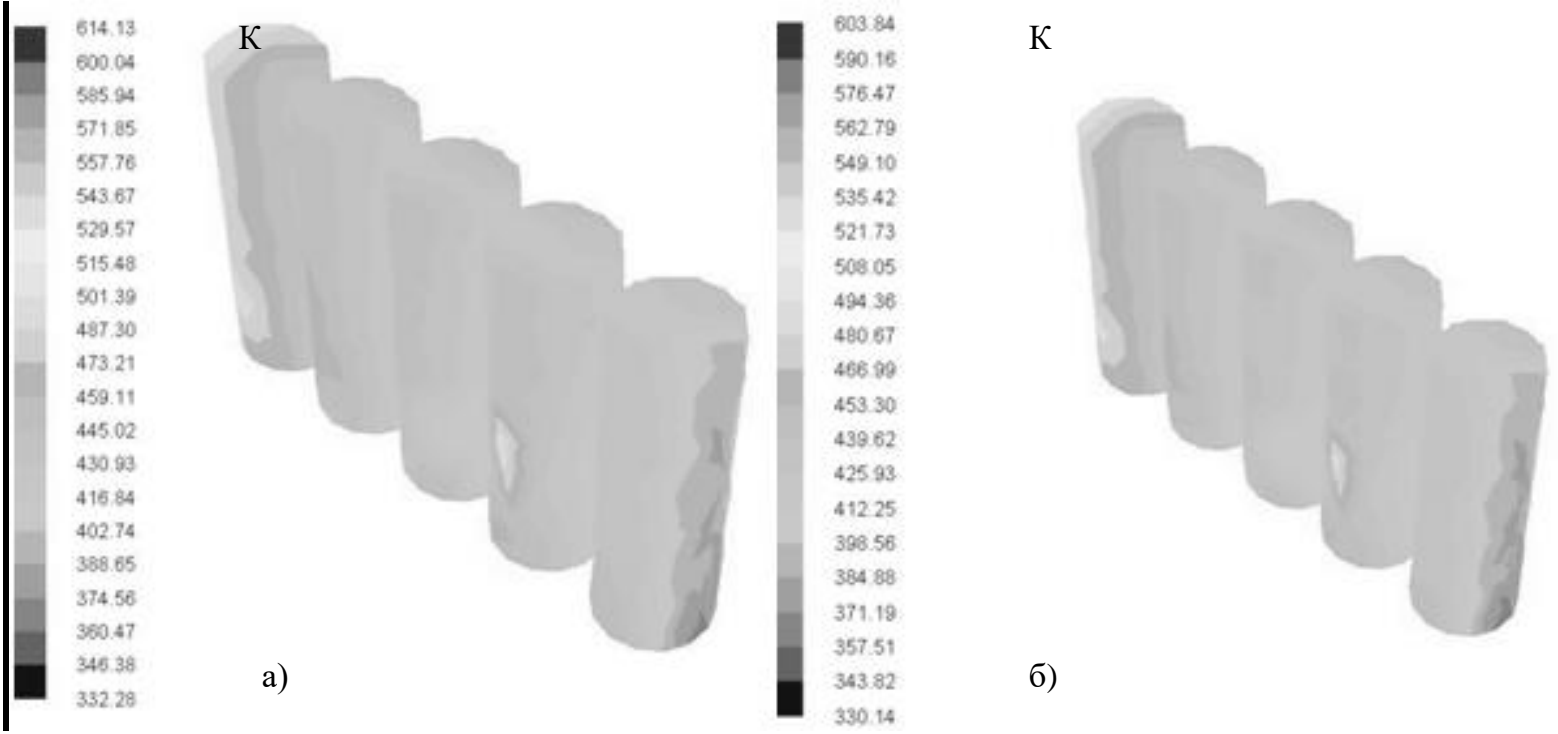

б)

Рисунок 3 - Температурні поля заготовок при нагріванні димовими газами напри кінець першого етапу:а) при надлишку повітря $a=1,2 ;$ б) при надлишку повітря $\mathrm{a}=1,1$

За результатами чисельного моделювання побудовано гістограми мінімальних та максимальних температур по всім заготовкам для даного етапу (рис. 4). 3 результатів видно, що середнє значення перепаду температур по всіх заготовках при надлишку повітря $a=1,2$ складає $17 \mathrm{~K}$, при надлишку повітря $a=1,1-15,2 \mathrm{~K}$.
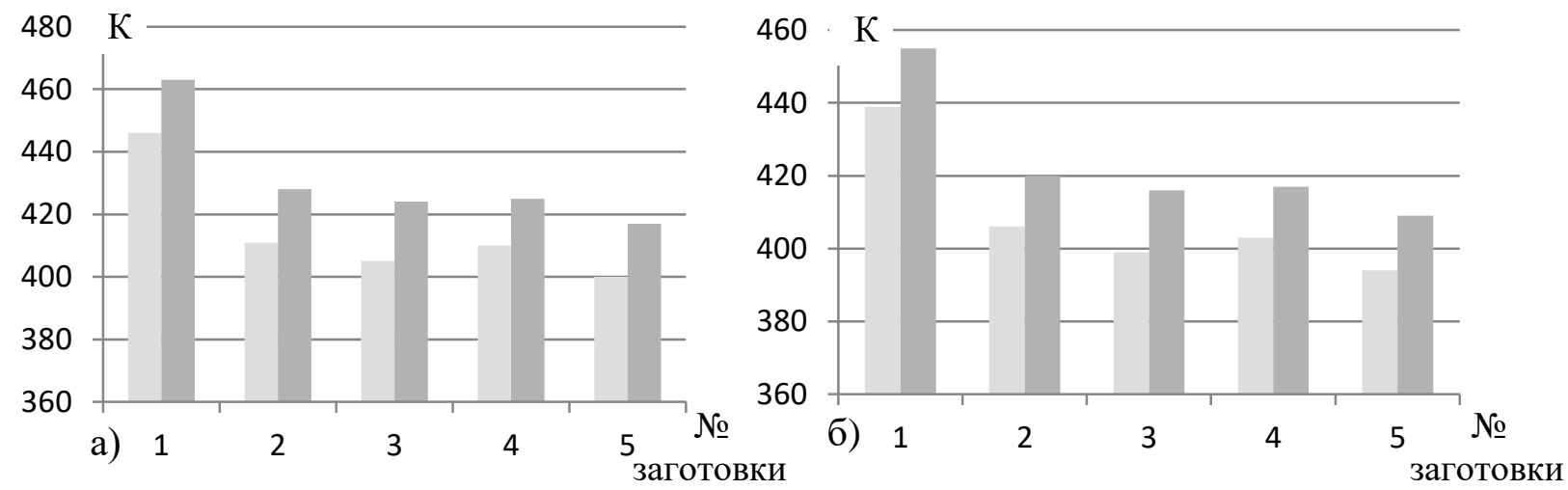

Рисунок 4 - Гістограма мінімальних та максимальних значень температури по заготовкам наприкінці першого етапу нагрівання: а) при надлишку повітря $\mathrm{a}=1,2 ;$ б) при надлишку повітря a=1,1

Як вказувалось вище процес нагрівання камери димовими газами відбувається у декількох камерах, кількість яких залежить від технологічної ситуації у процесі випалювання. У даному досліджені розглядаються 4 камери. Вище наведені результати дослідження для першої з них. Результати моделювання температурних режимів решти камер наведено у табл. 7.

Таблиця 7 - Результати моделювання нагрівання димовими газами 2-4 камер

\begin{tabular}{|l|c|c|}
\hline Назва параметру/Дослідження & №1 & №2 \\
\hline Надлишок повітря & $a=1,2$ & $a=1,1$ \\
\hline Камера 2 при максимальній температурі димових газів 953 К та розрідженні 39 Па \\
\hline Максимальна температура стінок вогневого колодязя & $666 \mathrm{~K}$ & $654 \mathrm{~K}$ \\
\hline
\end{tabular}


ISSN 1813-5420 (Print). Енергетика: економіка, технології, екологія. 2018. № 1

Продовження табл. 7

\begin{tabular}{|c|c|c|}
\hline $\begin{array}{l}\text { Мінімальна температура протилежних вогневим колодязям } \\
\text { стінок }\end{array}$ & $423 \mathrm{~K}$ & $416 \mathrm{~K}$ \\
\hline Перепад температури по всьому об’ємові касети & $243 \mathrm{~K}$ & $238 \mathrm{~K}$ \\
\hline Перепади температур по всьому об’ємові пересипки & $180 \mathrm{~K}$ & $180 \mathrm{~K}$ \\
\hline Середнє значення перепаду температури по всіх заготовках & $18,8 \mathrm{~K}$ & $17,4 \mathrm{~K}$ \\
\hline \multicolumn{3}{|c|}{ Камера 3 при максимальній температурі димових газів 1103 K та розрідженні 25 Па } \\
\hline Максимальна температура стінок вогневого колодязя & $805 \mathrm{~K}$ & $789 \mathrm{~K}$ \\
\hline $\begin{array}{l}\text { Мінімальна температура протилежних вогневим колодязям } \\
\text { стінок }\end{array}$ & $534 \mathrm{~K}$ & $523 \mathrm{~K}$ \\
\hline Перепад температури по всьому об’ємові касети & $271 \mathrm{~K}$ & $266 \mathrm{~K}$ \\
\hline Перепади температур по всьому об’ємові пересипки & $190 \mathrm{~K}$ & $190 \mathrm{~K}$ \\
\hline Середнє значення перепаду температури по всіх заготовках & $18 \mathrm{~K}$ & $17,4 \mathrm{~K}$ \\
\hline \multicolumn{3}{|c|}{ Камера 4 при максимальній температурі димових газів 1353 K та розрідженні 12 Па } \\
\hline Максимальна температура стінок вогневого колодязя & $967 \mathrm{~K}$ & $948 \mathrm{~K}$ \\
\hline $\begin{array}{l}\text { Мінімальна температура протилежних вогневим колодязям } \\
\text { стінок }\end{array}$ & $663 \mathrm{~K}$ & $647 \mathrm{~K}$ \\
\hline Перепад температури по всьому об’ємові касети & $305 \mathrm{~K}$ & $301 \mathrm{~K}$ \\
\hline Перепади температур по всьому об’ємові пересипки & $210 \mathrm{~K}$ & $210 \mathrm{~K}$ \\
\hline Середнє значення перепаду температури по всіх заготовках & $17 \mathrm{~K}$ & $22,6 \mathrm{~K}$ \\
\hline
\end{tabular}

На рис. 5-6 представлені графіки змін максимальних та мінімальних температур по кожній 3 заготовок наприкінці нагрівання димовими газами у всіх 4-х камерах.

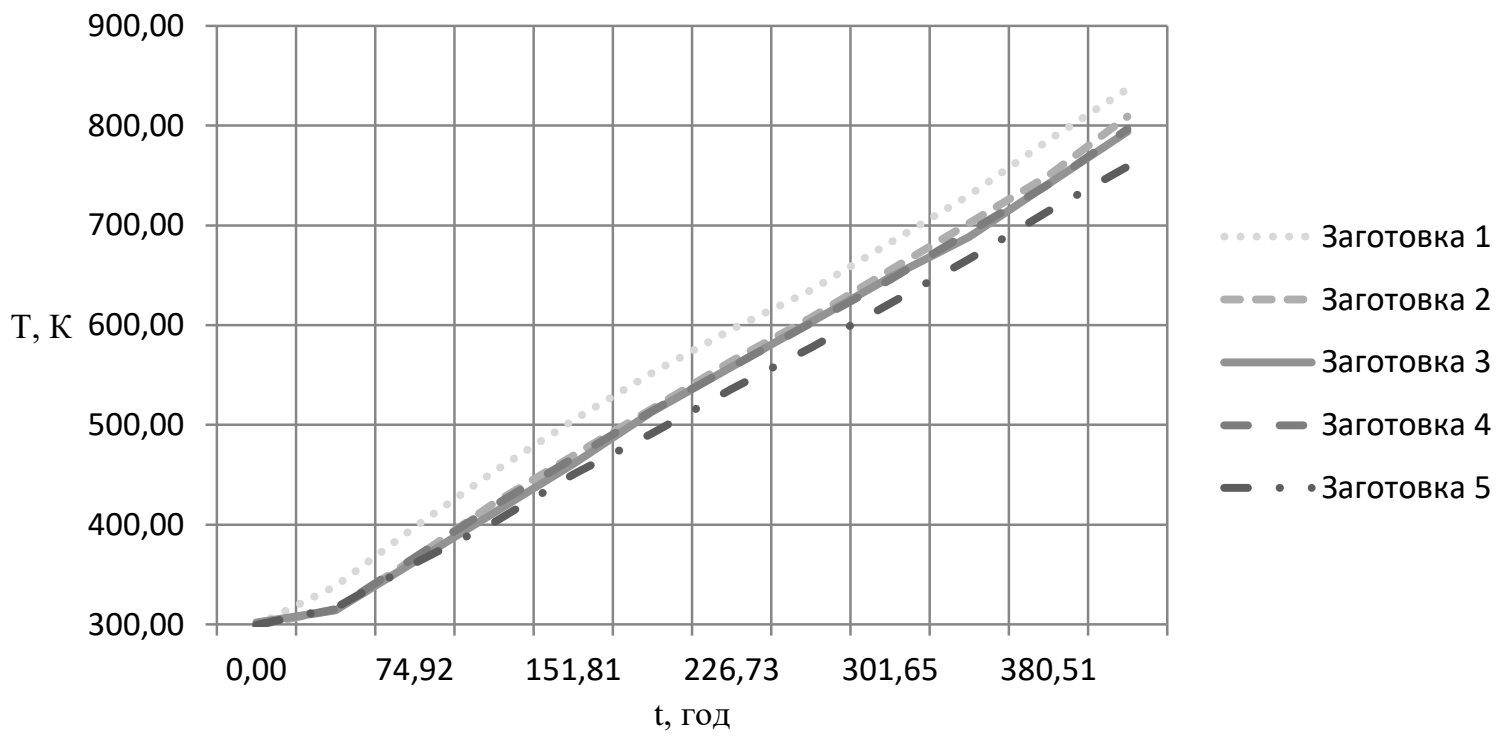

a) 


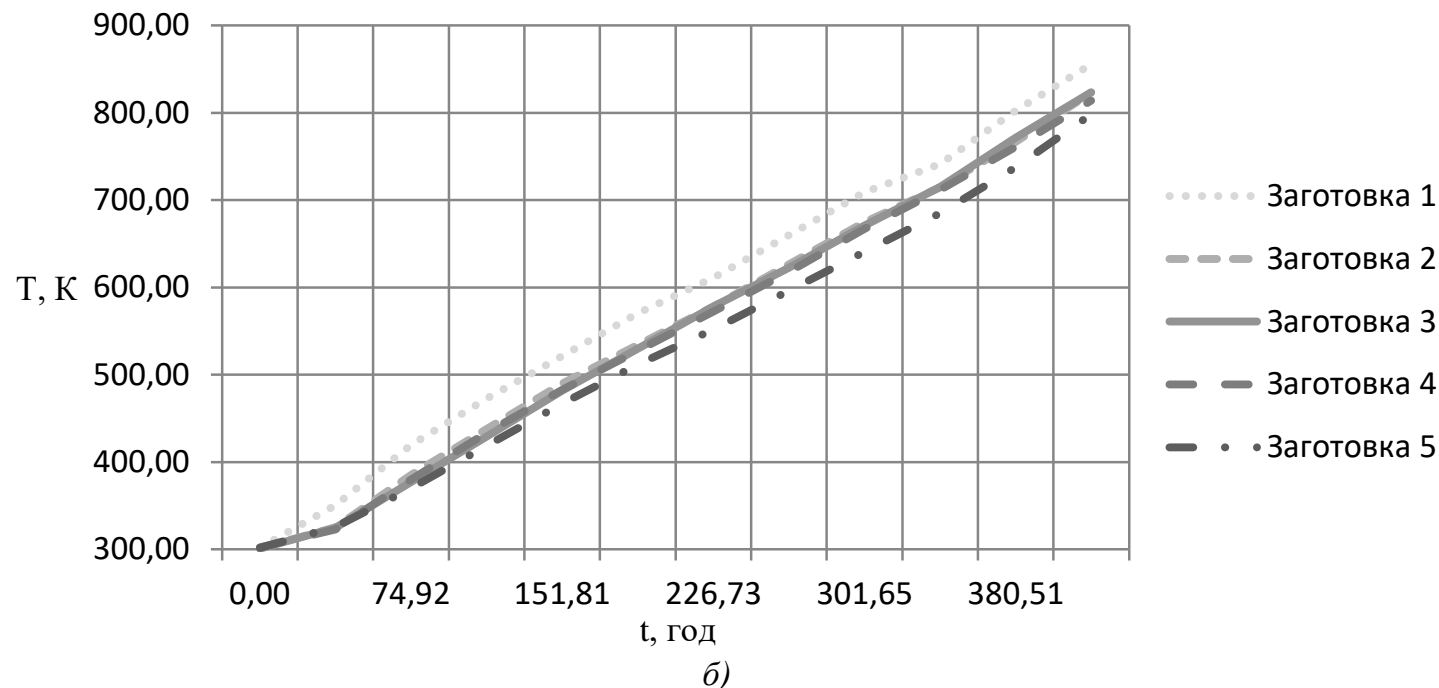

Рисунок 5 - Графіки зміни мінімальної (а) та максимальної (б) температур по заготовкам при надлишку повітря $\mathrm{a}=1,2$

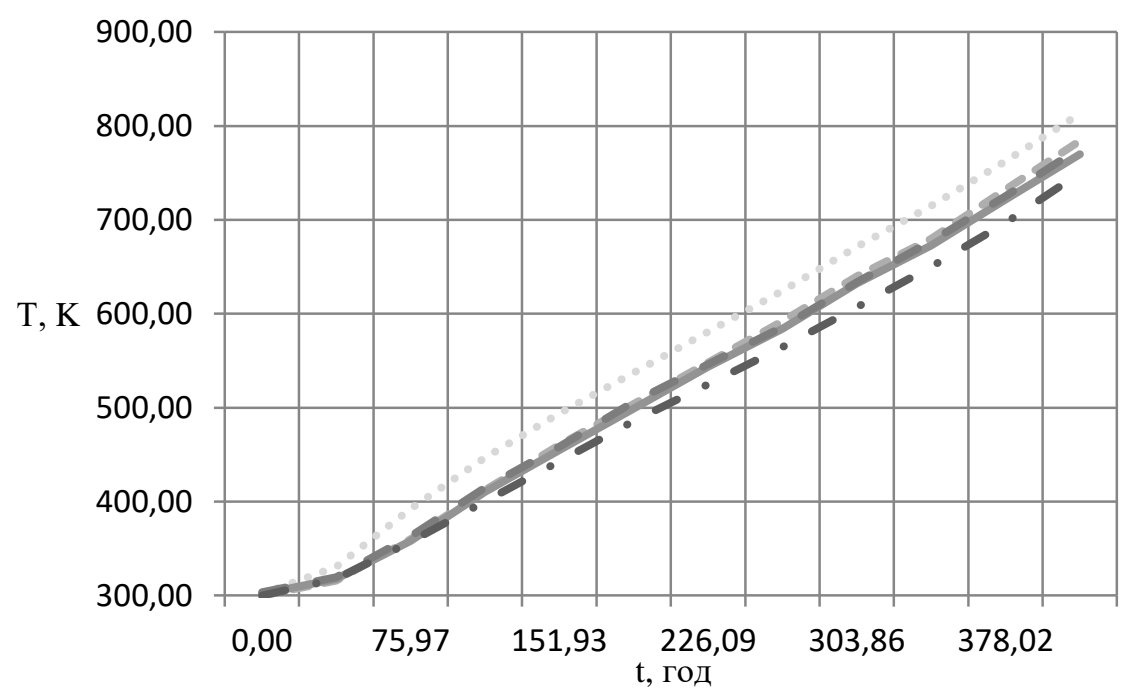

a)

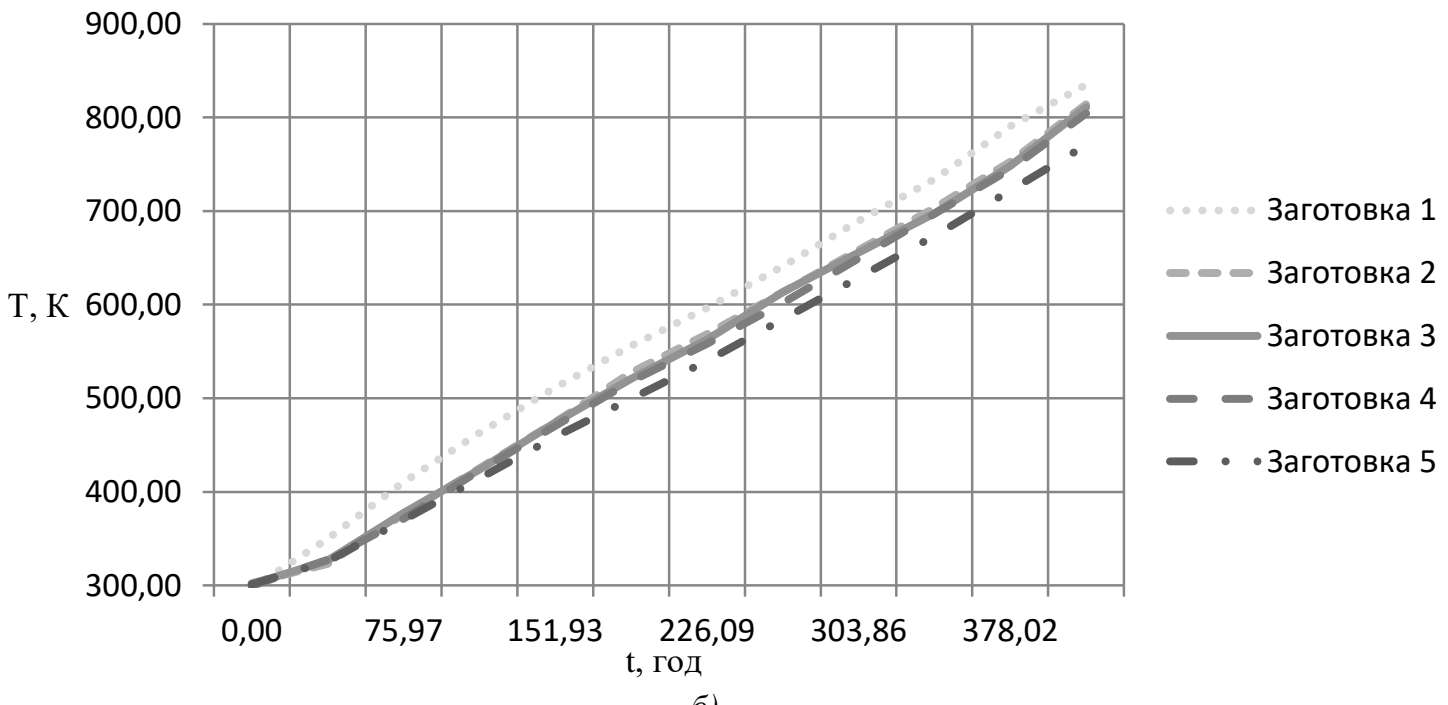

Заготовка 1

- Заготовка 2

Заготовка 3

- Заготовка 4

- • Заготовка 5

Рисунок 6 - Графіки зміни мінімальної (а) та максимальної (б) температур по заготовкам при надлишку повітря $\mathrm{a}=1,1$ 
За результатами чисельного моделювання побудовано гістограми мінімальних та максимальних температур по всім заготовкам наприкінці нагрівання камер печі димовими газами (рис 7). 3 результатів видно, що середнє значення перепаду температур по всіх заготовках при надлишку повітря $a=1,2$ складає 17 К, при надлишку повітря $a=1,1-22,6$ K.
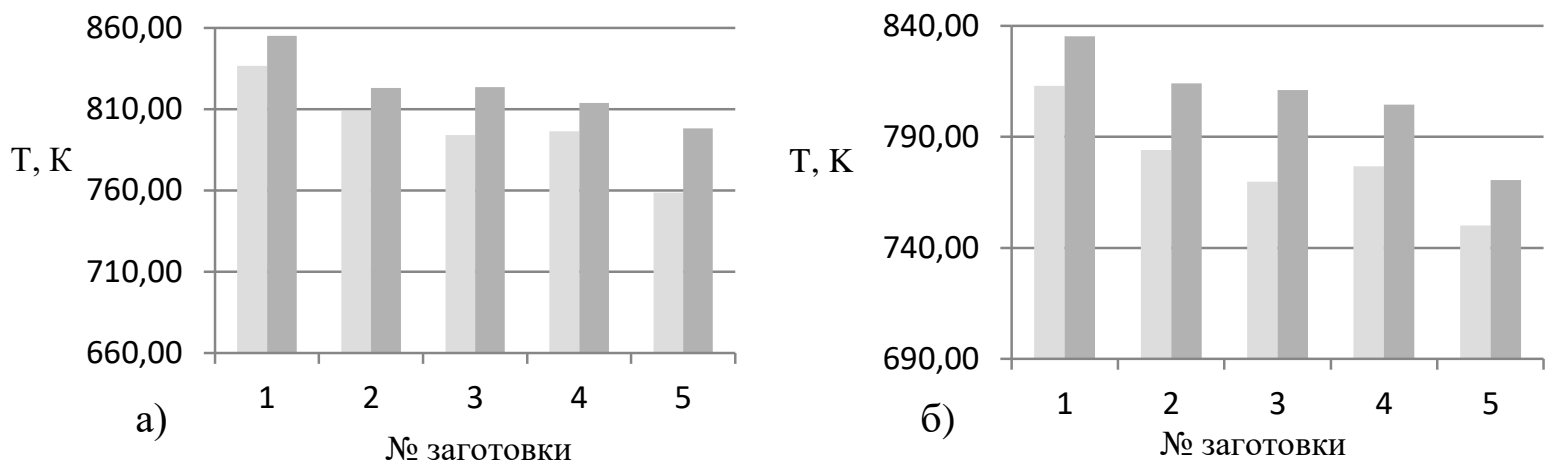

Рисунок 7 - Гістограма мінімальних та максимальних значень температури по заготовкам наприкінці нагрівання димовими газами: а) при надлишку повітря а=1,2; б) при надлишку повітря а=1,1

\section{Висновки}

Проведено дослідження впливу надлишку витрати повітря, що спалюється разом $з$ природним газом, на температурні поля камер печі випалювання вуглецевих виробів, які нагріваються димовими газами.

Наведений розрахунок витрати димових газів при різних значеннях надлишку витрати повітря.

Побудовані температурні поля камери печі та заготовок, на підставі яких проаналізовані перепади температур по заготовках, що суттєво впливають на якість вихідної продукції.

Представлені гістограми мінімальних та максимальних температур по заготовках наприкінці процесу нагрівання для різних режимів витрат повітря.

Наведені графіки зміни мінімальних та максимальних температур по заготовках протягом всієї стадії нагрівання димовими газами.

У подальших дослідженнях доцільно розглянути вплив інших технологічних параметрів (розрідження, витрати палива) на температурні поля камери печі при нагріванні димовими газами.

\section{Список використаної літератури}

1. Санников А. К. Производство электродной продукции / А. К. Санников, А. Б. Сомов, В. В. Ключников [и др.] - М. : Металлургия, 1985. - 128 с.

2. Лутков А. И. Тепловые и электрические свойства углеродных материалов / А. И. Лутков. - М. : Металлургия, 1990. - 175 с.

3. Чалых Е.Ф., Пащенкова Л.Ф. Печи электродных заводов Учебное пособие. - Москва: МХТИ им. Д.И. Менделеева, 1983. - 76 с.

4. А.c. 1755025 СССР. Способ укрытия теплоизоляционной шихты печи графитации /П. П. Сапко, В. П. Овсянников (СССР). - Открытия. Изобретения ; опубл. 1992, Бюл. № 30.

5. Угольные и графитовые электроды для электропечей и электролизеров / (Систематическое собрание патентов, сост. М. Б. Шварцберг). — Л.-М., 1938.

6. Левченко П.В. Расчеты печей и сушил иликатной промышленности Москва, Высшая школа, 1968. - 363 c. 
O. Zhuchenko, Cand. Sc. (Eng), Assoc. Prof., ORCID 0000-0001-5611-6529,

A. Korotynskyi, PhD student, ORCID 0000-0002-6309-5970

National Technical University of Ukraine «Igor Sikorsky Kyiv Polytechnic Institute»

\section{RESEARCH THE INFLUENCE OF EXCESS AIR ON THE PROCESS OF HEATING MULTI- CHAMBER BAKING FURNACE BY USING FLUE GASES}

Changing the parameters of the technological regime of the process of baking carbon products allows to achieve a qualitative thermal regime, which fully determines the quality of products. Investigation of the temperature field of the furnace depending on the technological parameters, and their rational use allows to achieve a lower output of defective products. Therefore, it is important to model these processes taking into account the maximum number of factors that will allow to minimize the time and cost of finished products.

Due to the fact that the research on industrial equipment is impossible for technical and economic reasons, as a method of research, mathematical modeling was used.

The study of the influence of excess air flow, burned together with natural gas, on the temperature fields of the furnace chamber at the stage of its heating by flue gases has been carried out. The regularities of the change in the mean value of the temperature drop across the blanks at different heating stages under different operating conditions were revealed. The features of the characteristic zones of the furnace during the process of heating the furnace chamber with flue gases are studied. The main attention of the research was paid to the issues of homogeneity of the temperature field of blanks, which significantly affects their quality.

Is given the calculation of the flow of flue gases at various values of excess air flow.

The temperature fields of the furnace chamber and the blanks have been constructed, on the basis of which the temperature drop across the blanks has been analyzed, which substantially affects the quality of the output product.

Are presented the histograms of the minimum and maximum temperatures on the blanks at the end of the heating process for different modes of air flow a

The graphs of changes in the minimum and maximum temperatures for blanks during the entire stage of heating by flue gases are given.

In further studies in this area, it is advisable to consider the influence of other technological parameters such as underpressure and fuel consumption on the temperature fields of the furnace chamber when heated by flue gases.

Keywords: burning of carbon products, flue gases, multi-chamber furnace, temperature fields, temperature difference, excess air.

\section{References}

1. Sannikov A. K. Proizvodstvo jelektrodnoj produkcii / A. K. Sannikov, A. B. Somov, V. V. Kljuchnikov [i dr.] - M. : Metallurgija, 1985. - $128 \mathrm{~s}$.

2. Lutkov A. I. Teplovye i jelektricheskie svojstva uglerodnyh materialov / A. I. Lutkov. - M. : Metallurgija, 1990. - $175 \mathrm{~s}$.

3. Chalyh E.F., Pashhenkova L.F. Pechi jelektrodnyh zavodov Uchebnoe posobie. - Moskva: MHTI im. D.I. Mendeleeva, 1983. - 76 s.

4. \A.s. 1755025 SSSR. Sposob ukrytija teploizoljacionnoj shihty pechi grafitacii /P. P. Sapko, V. P. Ovsjannikov (CCCR). — Otkrytija. Izobretenija ; opubl. 1992, Bjul. № 30.

5. Ugol'nye i grafitovye jelektrody dlja jelektropechej i jelektrolizerov / (Sistematicheskoe sobranie patentov, sost. M. B. Shvarcberg). - L.-M., 1938.

6. Levchenko P.V. Raschety pechej i sushil ilikatnoj promyshlennosti Moskva, Vysshaja shkola, 1968. $363 \mathrm{~s}$.

Надійшла 15.04.2018

Received 15.04.2018 